Review

\title{
The Importance of Maintaining Protected Zone Status against Bemisia tabaci
}

\section{Andrew G. S. Cuthbertson ${ }^{1, *}$ and Irene Vänninen ${ }^{2}$}

1 Fera, Sand Hutton, York YO41 1LZ, UK

2 Natural Resources Institute Finland, Tietotie 2C, Jokioinen FI-31600, Finland;

E-Mail: irene.vanninen@luke.fi

* Author to whom correspondence should be addressed; E-Mail: andrew.cuthbertson@fera.co.uk; Tel.: +44-019-0446-2201; Fax: +44-019-0446-2111.

Academic Editor: Brian T. Forschler

Received: 13 February 2015 / Accepted: 5 May 2015 / Published: 11 May 2015

\begin{abstract}
The sweetpotato whitefly, Bemisia tabaci (Gennadius) (Hemiptera: Aleyrodidae) is a major pest of economically important crops worldwide. Both the United Kingdom (UK) and Finland hold Protected Zone status against this invasive pest. As a result B. tabaci entering these countries on plants and plant produce is subjected to a policy of eradication. The impact of B. tabaci entering, and becoming established, is that it is an effective vector of many plant viruses that are not currently found in the protected zones. The Mediterranean species is the most commonly intercepted species of B. tabaci entering both the UK and Finland. The implications of maintaining Protected Zone status are discussed.
\end{abstract}

Keywords: Bemisia tabaci; eradication; protected zone

\section{Introduction}

The sweetpotato whitefly, Bemisia tabaci (Gennadius) (Hemiptera: Aleyrodidae) is a major pest of economically important crops worldwide [1]. Bemisia tabaci damages crops by feeding on phloem sap and the large amounts of sticky honeydew produced can lower the rate of leaf photosynthesis. This whitefly is also a vector of many plant viruses [2-4].

The pest status of $B$. tabaci insects is complicated by the recognition of 11 well-defined genetic groups and at least 34 morphocryptic species, which are morphologically identical but distinguishable at the molecular level [5-8]. Formerly, the term biotype was used to define and discriminate $B$. tabaci 
populations with very different biological characteristics, including invasiveness, insecticide resistance profile, vector competence, and host ranges [9]. It is the former B biotype (now known as Middle East-Asia Minor 1 (MEAM1) species) and Q biotype (now known as Mediterranean species) that are the most invasive and damaging $B$. tabaci species around the world, presenting the greatest threat to glasshouse crops $[10,11]$. The damaging MEAM1 is an aggressive colonizer and it is an effective vector of viruses, whereas the Mediterranean species characteristically shows strong resistance to novel insecticides $[10,12,13]$.

\section{Economic Importance of Protected Zone Status}

Bemisia tabaci is listed in the European Union (EU) Plant Health Directive 2000/29/EC under Annex 1AI (non-European populations) as a harmful organism, whose introduction from non-EU countries into, and spread within, all EU member states shall be banned [14]. The United Kingdom (UK) and Finland are currently two member states (along with Sweden, Republic of Ireland and parts of Portugal) that remain free of all populations of B. tabaci and maintain Protected Zone (PZ) status against this pest [14-16]. The establishment of B. tabaci within a Protected Zone area, for example the $\mathrm{UK}$, poses a threat to the horticultural industry, in particular to the tomato industry. MEAM1, in particular, can transfer and infect tomatoes with both Tomato Yellow Leaf Curl Virus (TYLCV) and Tomato Yellow Leaf Curl Sardinia Virus (TYLCSV) and, depending on the timing of infection, losses can reach $100 \%$ [17]. The only reference to the economic burden of B. tabaci and its associated viruses becoming established in the UK is outlined in Morgan and MacLeod [18]. It is estimated that a single producer might reduce their profit margins by around $£ 5500$ per 0.1 ha, while the national industry might suffer losses of around $£ 11.5 \mathrm{M}$. Though outdated, these figures highlight the need for suitable pest management strategies to be developed to avoid significant financial loss to the UK tomato industry.

\section{Bemisia tabaci Interceptions}

Within Europe, B. tabaci is established in the Mediterranean coastal regions and, even with an estimated temperature increase of $2^{\circ} \mathrm{C}$, expansion of areas where the pest can establish will still be very distant from the northern European countries with PZ status [19]. The PZ status for Portuguese islands, in which climatic conditions are suitable for $B$. tabaci, is maintained only by exclusion of the pest.

Within the UK, B. tabaci has been intercepted at growing sites on an extremely wide range of hosts at nurseries since 1987 [15]. Interceptions of B. tabaci coming into the UK would appear to follow no pattern with numbers of interceptions from source countries varying widely and with the majority of outbreaks being associated with Euphorbia pulcherrima (poinsettia) plants (Figure 1) [15,16]. Historically, it has been MEAM1 that has been entering the UK, but recently there has been a shift to Mediterranean species [7,20]. Mediterranean species is widely considered to evolve stable resistance to neonicotinoid insecticides more rapidly when compared to MEAM1 species [21]. As a result, Mediterranean species neonicotinoid resistance is becoming increasingly widespread and problematic, with numerous cases being reported world-wide [22,23]. 


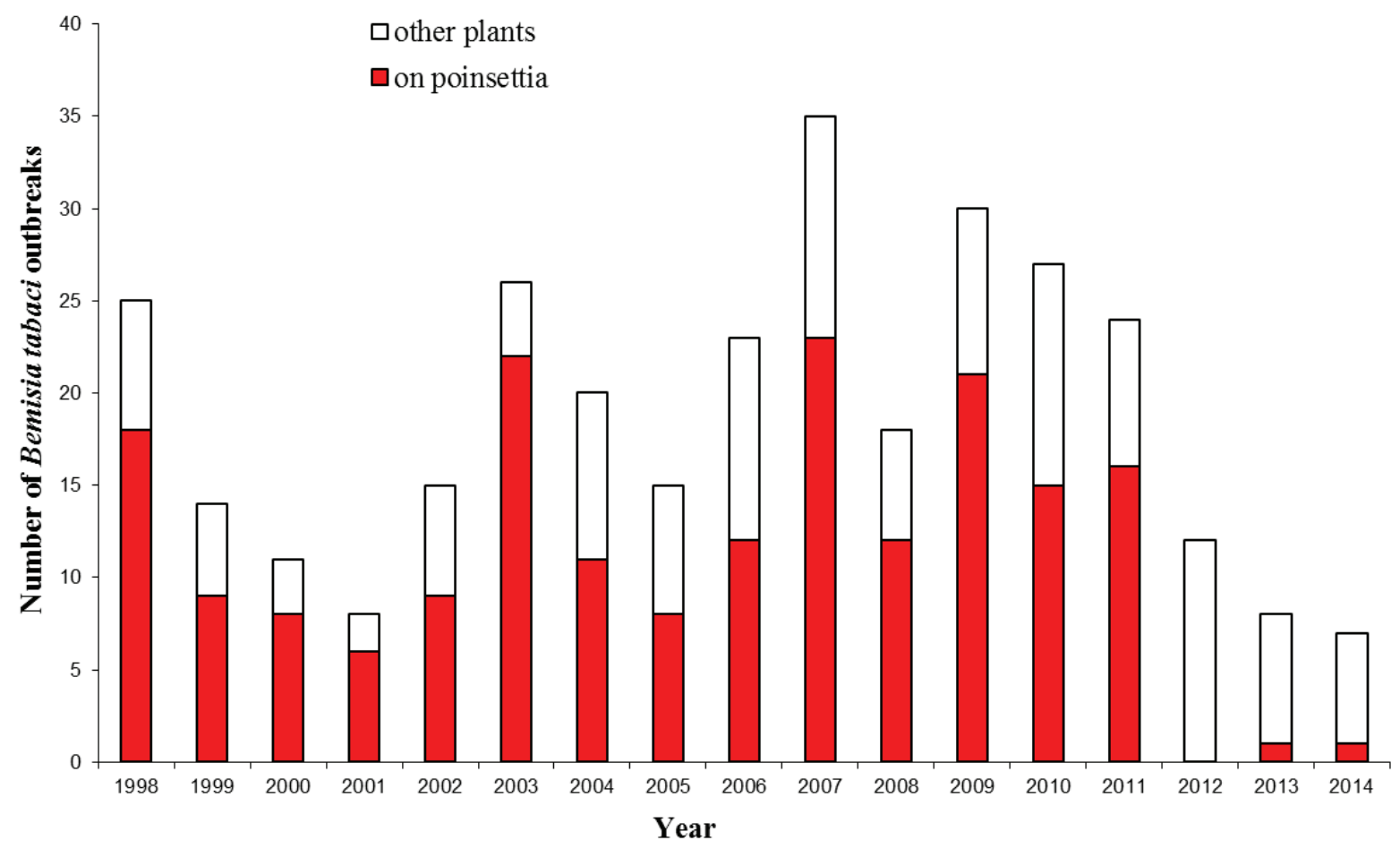

Figure 1. The number of Bemisia tabaci outbreaks in England and Wales (1998-2014) (updated from Cuthbertson [15]).

Both the Mediterranean and MEAM1 species are also regularly intercepted and, as a result, undergo a process of eradication in Finland [24]. The majority of outbreaks in production places, having numbered 16-83 per year since 2009, have been on poinsettia originating from a number of countries in the EU [25]. During recent years, however, Bemisia has also increasingly entered on imported bedding and pot plants, particularly on Mandevilla, in the spring-time [26]. This development may, in principle, increase the potential of the species spreading between infested production places during the summer time before eradication is complete, or when plants with non-detected Bemisia are planted outdoors. The Mediterranean species, due to its tendency of resistance development and, among other things, better development rates at both high and low temperatures [27], is estimated to pose a somewhat bigger threat to Finnish plant production than MEAM1 [28].

\section{Impact of Bemisia tabaci Establishment}

Impact is predominantly related to diseases caused by $B$. tabaci transmitted viruses on crops and particularly by those begomoviruses causing yellow leaf curl diseases in tomato, which have a severe impact on crop cultivation and yield in all regions where tomato is grown. The synergy between the two highly invasive whitefly species (MEAM1 and Mediterranean) and both TYLCV and TYLCSV, which are highly infectious to tomato (as well as pepper and beans), efficiently transmitted by B. tabaci and adaptable to environments where tomato is cultivated, are characteristics of an invasive virus. Most B. tabaci transmitted viruses cause high impact in crops and, generally, losses from those virus diseases can be considered as very economically important [17].

Thus far there are no known introductions of Bemisia-associated viruses in Finland, and the likelihood of TYLCV/TYLCSV entering and establishing in Finland via the pathway of imported ornamental 
plants is considered small [14]. This is because ornamental plants imported into the country, with the exception of Lisianthus [29] are either not hosts, or are not good hosts, for the virus [14]. Furthermore, vegetable plants for planting do not form an important pathway of introduction for the insect or viruses, at least not for the moment, since professional Finnish vegetable producers only use domestic plants for planting. Such functional isolation from the main introduction pathways, coupled with unsuitable outdoor conditions for permanent establishment of the insect itself, scarcity of TYLCV/TYLCSV natural host plants outdoors that could serve as a reservoir for the virus, and the presumably low back-transmission of the virus from non-solanaceous hosts to tomato [30], are all bonus factors that, when coming together, help preserve the PZ area free of Bemisia and TYLCV/TYLCSV.

There are three major knowledge gaps with respect to the impact of Bemisia-transmitted plant viruses in the PZs. Firstly, it is not known what proportion of the intercepted insects are viruliferous, and how often virus-infested but symptomless plants enter the country together with the vector. It is known that viruliferous insects do sometimes arrive into PZ areas as TYLCSV has been recently detected in B. tabaci entering the UK [20]. Secondly, it is not known how effectively the vector can acquire and transmit TYLCV/TYLSCV from infested but symptomless plants such as E. pulcherrima that are regularly imported to the $\mathrm{PZ}$ countries and are often infested with $B$. tabaci. The vector can acquire TYLCV/TYLCSV from some symptomless non-solanaceous host plants [31], whereas from others acquisition rates are very low due to low titres of virus in the symptomless plants [30]. Finally, the likelihood of B. tabaci, either with or without plant viruses, moving from ornamentals to vegetable production in the $\mathrm{PZ}$ countries is not known. For viruses entering with $B$. tabaci on ornamentals, there is a risk of outbreaks when tomato and ornamentals are grown in the same environment at the same time. Such virus outbreaks can be eliminated if detected in time, as exemplified by an eradication campaign conducted in The Netherlands in 2007 [32], specifically when the vector is not present. TYLCV has been shown to arrive also in imported fruits [33], and the virus can be acquired and transmitted from tomato fruit by the vector [34]. However, the transfer of the virus from such fruits to vegetable production is impossible unless the vector is also present, gets access to the fruits and then re-enters vegetable glasshouses.

The likelihood of $B$. tabaci moving from ornamentals to vegetable production needs to be understood better to be able to estimate impacts of $B$. tabaci establishing in PZ countries. Imported ornamentals were most likely the initial access route for the glasshouse whitefly Trialeurodes vaporariorum to Finnish vegetable production; currently this pest is causing the most problems in vegetable production owing to changes in production strategies. Heikkilä and Vänninen [35] used stochastic spatial simulation modeling for analyzing what would happen under different scenarios of $B$. tabaci spreading from ornamentals to vegetable production. The likelihood of the move depends on issues such as the geographical proximity of ornamental and vegetable production sites, the extent to which the pest can be controlled in ornamental production, and the logistic networks of traded ornamentals within the country. These factors are coupled with outdoor conditions that impact pest mortality to a higher or lesser extent should the pest attempt spreading through the outdoor environment. The results are likely to differ by PZ country since conditions influencing the spread of the pest vary.

The establishment potential and impacts of the pest itself, in the absence of plant viruses, should be estimated taking specific characteristics of glasshouse production in each PZ into account. A characteristic feature of Finnish glasshouse horticulture is year-round production using artificial 
lighting. In these conditions, T. vaporariorum can be used as a proxy for exploring the establishment, spread and impacts of $B$. tabaci. In production clusters particularly, the advent of year-round production from the 1990s onwards has resulted in region wide management difficulties of the glasshouse whitefly in both the new and the old (seasonal) production forms. The growers routinely apply preventive control against the glasshouse whitefly in both tomato and cucumber, since practically all crops get infested at some point of the cropping cycle [36]. Year-round crops would provide good conditions for reproduction and survival of B. tabaci in terms of temperature [37] and daylength of 16-20 hours [38,39]. Uninterrupted cropping cycles would enable the production of 8-10 generations per year. It is likely that the year-round production, with time, would enable the establishment and uninterrupted persistence of B. tabaci in Finnish vegetable production in the same way as T. vaporariorum now persists and spreads there, especially in production clusters [40,41].

\section{Maintaining Protected Zone Status}

If PZ status was to be lifted for PZ countries, restrictions from Annex IV, Part A, Section I banning introduction and spread of non-European $B$. tabaci populations would still apply. Revoking the status would place PZ countries in a similar position to other northern countries where B. tabaci cannot establish, with systematic inspections limited to material imported from outside the EU. For host material produced within the EU, there would be no routine response to outbreaks or pre-emptive measures including statutory inspections. A free flow of EU traded commodities would likely increase occurrences and outbreaks of B. tabaci and with that the likelihood that viruses are transmitted to significant crops, tomato and cucurbits, causing high impact and severe crop losses. Maintaining the PZ status with the current Annex 1AI status would still support the zero tolerance approach towards B. tabaci, regardless of its origin with the benefit of a significantly reduced risk of entry of $B$. tabaci and the viruses it transmits. A UK Plant Health consultation on the future of PZ status in the UK [42], had an overwhelming response to maintain the status quo.

According to Defra [42], calculated cost benefit ratios of several impact scenarios were produced for protected salad crops (cucumber and tomatoes). The ratios ranged from 1:1.2 to 1:30 depending on the scenario and crop; these results therefore would support maintenance of the PZ. The analysis in the Defra [42] report concludes that although the total annual costs (to both industry and government) of eradicating $B$. tabaci are large, they are considerably less than the potential benefits obtained by excluding the pest. The potential impact of the pest (and vectored diseases) in terms of crop losses in salad crops potentially being much more important than the effect of the pest in terms of increasing the costs associated with controlling it. The loss of PZ would mean that growers of ornamental crops would have to control (but not eradicate) both B. tabaci and T. vaporariorum; however, salad growers could be confronted for the first time with the problem of controlling B. tabaci as well as $T$. vaporariorum whereas currently they have only had to deal with $T$. vaporariorum. Studies suggest that in tomato $B$. tabaci can replace $T$. vaporariorum due to the former's superior competitive abilities [43]. Having to deal with two or more pest species that are dynamically establishing their competitive roles adds to the complexity of pest management.

In Finland, the debate about PZ status has been accentuated by a new plant health law according to which eradication costs of $B$. tabaci are no longer compensated for by government funds. Even so, the 
status quo was maintained due to risks associated with the Bemisia-vectored plant viruses and the specificities of Finnish vegetable production with highly conducive conditions for the pest's reproduction. A cost-benefit analysis (CBA) of the PZ for a number of scenarios was conducted by Heikkilä [44]. The three scenarios for maintaining the PZ assumed that the annual number of infested ornamental glasshouses either remains at 50 per year, or doubles or triples by 2038. The two scenarios for abolishing the PZ assumed either that Bemisia spreads in six years to all poinsettia and in 30 years to about one sixth of the total cucumber and tomato area, or alternatively that the spread on tomato is faster than this. Accounting for uncertainty regarding the costs of control, the benefit:cost ratio was estimated to be $0.52-2.63$. This means that it could not be established with certainty whether to abolish or to maintain the PZ. Given the baseline parameter values, however, five of the six scenario comparisons favoured maintaining the PZ. The CBA also concluded that if Bemisia would spread to tomato or cucumber production and cause even moderate crop losses, maintaining the $\mathrm{PZ}$ would always be profitable. If, on the other hand, the risk of Bemisia spreading to vegetable production was small and the costs of control on flower farms remained moderate, then giving up the PZ could be an option. The CBA did not include Bemisia-associated viruses in the scenarios, but only the insect itself as a pest.

The Mediterranean species of the $B$. tabaci species complex predominates in specimens entering both the UK and Finland. Therefore, control and eradication programmes need to be able to deal with this species [45]. Most importantly, the propensity for Mediterranean species to develop strong insecticide resistance very clearly suggests that the control options available in PZ countries may not always be sufficient to eradicate the pest, particularly in outbreak situations in ornamental nurseries [46]. Furthermore, B. tabaci species other than MEAM1 or Mediterranean are now also becoming more common on imported plant material [47]. Determining their status in the future is also of importance in order to fully understand the consequences of their potential outbreak and establishment. As a result, monitoring for Bemisia cryptic species and resistance status, as well as the presence of plant viruses in the intercepted insects [20], are important facets in ensuring that PZ glasshouse horticulture remains free from this highly damaging invasive pest in the future.

\section{Conclusions}

Bemisia tabaci is a worldwide pest and major virus vector. Originally known as a pest of sub-tropical crops, the species is now widely distributed under glass in temperate areas including most of Europe and on outdoor crops in southern Europe. Currently, it is not established in the UK or Finland. However, it could establish in protected environments, where it has the potential to be a major pest, particularly of glasshouse salad crops such as tomato and cucumber, given its potential to spread damaging viruses. The co-existence of year-round and seasonal vegetable production may specifically increase the establishment potential of the pest if it was to move from ornamental production to vegetable crops. The maintenance of protected zone status offers countries like the UK and Finland better control over their respective borders in regards to plant imports and in terms of protecting against introductions on EU traded material. Keeping the respective countries free from highly damaging plant viruses is vital to maintaining a healthy protected horticultural industry. 


\section{Acknowledgments}

The work was funded by the Department for Environment, Food and Rural Affairs (Defra), UK, and the Finnish horticultural foundation of Nikolai and Ljudmila Borisoff.

\section{Author Contributions}

Both authors contributed equally to the manuscript.

\section{Conflicts of Interest}

The authors declare no conflict of interest.

\section{References and Notes}

1. Xu, C.; Qiu, B.-L.; Cuthbertson, A.G.S.; Zhang, Y.; Ren, S.-X. Adaptability of sweetpotato whitefly Bemisia tabaci (Hemipetera: Aleyrodidae) on seven marginal host plants. Int. J. Pest Manage. 2012, 58, 297-301.

2. Oliveira, M.R.V.; Henneberry, T.J.; Anderson, P. History, current status and collaborative research projects for Bemisia tabaci. Crop Prot. 2002, 20, 709-723.

3. Perring, T.M. The Bemisia tabaci species complex. Crop Prot. 2001, 20, 725-737.

4. Jones, D.R. Plant viruses transmitted by whiteflies. Eur. J. Plant Pathol. 2003, 109, 195-219.

5. Dinsdale, A.; Cook, L.; Riginos, C.; Buckley, Y.M.; De Barro, P. Refined global analysis of Bemisia tabaci (Hemiptera: Sternorrhyncha: Aleyrodoidea: Aleyrodidae) mitochondrial cytochrome oxidase 1 to identify species level genetic boundaries. Ann. Entomol. Soc. Am. 2010, 103, 196-208.

6. De Barro, P.J.; Liu, S.S.; Boykin, L.M.; Dinsdale, A.B. Bemisia tabaci: A statement of species status. Ann. Rev. Entomol. 2011, 56, 1-19.

7. Powell, M.E.; Cuthbertson, A.G.S. Pest control: Distinguishing between different biotypes of Bemisia tabaci in the UK. The Biologist 2013, 60, 18-21.

8. Boykin, L.M.; De Barro, P.J. A practical guide to identifying members of the Bemisia tabaci species complex: And other morphologically identical species. Front. Ecol. Evol. 2014, 45, 1-5.

9. Shatters, R.G.; Powell, C.A.; Boykin, L.; Liansheng, H.; McKenzie, C.L. Improved DNA barcoding method for Bemisia tabaci and related Aleyrodidae: Development of universal and Bemisia tabaci biotype-specific mitochondrial cytochrome c oxidase I polymerase chain reaction primers. J. Econ. Entomol. 2009, 102, 750-758.

10. Bethke, J.A.; Byrne, F.J.; Hodges, G.S.; McKenzie, C.L.; Shatters, R.G. First record of the Q biotype of the sweetpotato whitefly, Bemisia tabaci, in Guatemala. Phytoparasitica 2009, 37, 61-64.

11. Qiu, B.-L.; Dang, F.; Li, S.-J.; Ahmed, M.Z.; Jin, F.-L.; Ren, S.-X.; Cuthbertson, A.G.S. Comparison of biological parameters between the invasive B biotype and a new defined $\mathrm{Cv}$ biotype of Bemisia tabaci (Hemiptera: Aleyradidae) in China. J. Pest Sci. 2011, 84, 419-427.

12. Jones, C.M.; Gorman, K.; Denholm, I.; Williamson, M.S. High-throughput allelic discrimination of B and Q biotypes of the whitefly, Bemisia tabaci, using TaqMan allele-selective PCR. Pest Manag. Sci. 2008, 64, 12-15. 
13. McKenzie, C.L.; Hodges, G.; Osborne, L.; Byrne, F.J.; Shatters, R.G. Distribution of Bemisia tabaci (Hemiptera: Aleyrodidae) biotypes in Florida - investigating the Q invasion. J. Econ. Entomol. 2009, 102, 670-676.

14. EFSA (European Food Safety Authority). Scientific opinion on the risks to plant health posed by Bemisia tabaci species complex and viruses it transmits for the EU territory. EFSA J. 2013, 11, doi:10.2903/j.efsa.2013.3162.

15. Cuthbertson, A.G.S. Update on the status of Bemisia tabaci in the UK and the use of entomopathogenic fungi within eradication programmes. Insects 2013, 4, 198-205.

16. Cuthbertson, A.G.S.; Blackburn, L.F.; Eyre, D.P.; Cannon, R.J.C.; Millar, J.; Northing, P. Bemisia tabaci: The current situation in the UK and the prospect of developing strategies for eradication using entomopathogens. Insect Sci. 2011, 18, 1-10.

17. Cathrin, P.B.; Ghanim, M. Recent advances on interactions between the whitefly Bemisia tabaci and begomoviruses, with emphasis on tomato yellow leaf curl virus. In Plant Virus-Host Interaction: Molecular Approaches and Viral Evolution; Elsevier: Amsterdam, The Netherlands, 2014; pp. 79-103.

18. Morgan, D.; MacLeod, A. Assessing the economic threat of Bemisia tabaci and tomato yellow leaf curl virus to the tomato industry in England and Wales. Proc. BCPC Conf. 1996, 3, 1077-1082.

19. Gilioli, G.; Pasquali, S.; Parisi, S.; Winter, S. Modelling the potential distribution of Bemisia tabaci in Europe in light of the climate change scenario. Pest Manag. Sci. 2014, 70, 1611-1623.

20. Powell, M.E.; Cuthbertson, A.G.S.; Boonham, N.; Morris, J.; Bell, H.A.; Northing, P. First record of the Q Biotype of the sweetpotato whitefly, Bemisia tabaci, intercepted in the UK. Eur. J. Plant Pathol. 2012, 133, 797-801.

21. Nauen, R. Insecticide resistance in European agriculture: Research instead of rumours. In Proceedings BCPC International Congress-Crop Science \& Technology, BCPC, Alton, Hants, UK, 2005; Vol. 3A-1, 123-130.

22. Fernandez, E.; Gravalos, C.; Haro, P.J.; Cifuentes, D.; Bielza, P. Insecticide resistance status of Bemisia tabaci Q biotype in south-eastern Spain. Pest Manag. Sci. 2009, 65, 885-891.

23. Wang, Z.; Yan, H.; Yang, Y.; Wu, Y. Biotype and insecticide resistance status of the whitefly Bemisia tabaci in China. Pest Manag. Sci. 2010, 66, 1360-1366.

24. Lemmetty, A.; Vänninen, I. Bemisia tabaci biotype Q determined for the first time on poinsettia crops in Finland and Sweden. Ann. Zool. Fennici 2014, 51, 501-506.

25. The Finnish Food Safety Authority (Evira). New occurrences of regulated pest species 2009-2013. Available online: http://www.evira.fi/files/attachments/fi/kasvit/kasvinterveys/tuhoojatilasto_2009-2013.pdf (accessed on 31 January 2015).

26. The Finnish Food Safety Authority (Evira). Kasvinterveysyksikön valvontaraportti 2013. (Monitoring report for 2013 by the Plant Health Unit of the Finnish Food Safety Authority) (in Finnish). Available online: http://www.evira.fi/portal/fi/tietoa\%2Bevirasta/julkaisut/?a=view\&productId=377 (accessed on 31 January 2015).

27. Muñiz, M.; Nombela, G. Differential variation in development of the B- and Q-biotypes of Bemisia tabaci (Hemiptera: Aleyrodidae) on sweet pepper at constant temperatures. Environ. Entomol. 2001, 30, 720-727. 
28. Hannunen, S.; Heikkilä, J.; Tuomola, J. A model for ranking plant pests and diseases (FinnPRIO). Available online: http://ageconsearch.umn.edu/bitstream/182970/2/EAAE2014_Prio_fullpaper_24062014.pdf (accessed on 31 January 2015).

29. Cohen, J.; Gera, A.; Ecker, R.; Ben Joseph, R.; Perlsman, M.; Gokkes, M.; Lachman, O.; Antignus, Y. Lisianthus leaf curl a new disease of Lisianthus caused by tomato yellow leaf curl virus. Plant Dis. 1995, 79, 416-420.

30. Ioannou, N.; Kyriakou, A.; Hadjinicolis, A. Host range and natural reservoirs of tomato yellow leaf curl virus. Agricultural Research Institute, Ministry of Agriculture and Natural Resources, Finland. Tech. Bull. 1987, 85, 1-7.

31. Polston, J.E.; Cohen, L.; Sherwood, T.A.; Ben-Joseph, R.; Lapidot, M. Capsicum species: Symptomless hosts and reservoirs of tomato yellow leaf curl virus. Phytopathology 2006, 96, 447-452.

32. NPPS (Netherlands Plant Protection Service). Tomato Yellow Leaf Curl Virus (TYLCV-Alm) on Solanum lycopersicum (Tomato) Plants. Ministry of Agriculture, Nature and Food Quality: Wageningen, The Netherlands. Pest Report 2007; pp. 2.

33. Just, K.; Leke, W.N.; Sattar, M.N.; Luik, A.; Kvarnheden, A. Detection of tomato yellow leaf curl virus in imported tomato fruit in northern Europe. Plant Pathol. 2014, 63, 1454-1460.

34. Delatte, H.; Dalmon, A.; Rist, D.; Soustrade, I.; Wuster, G.; Lett, J.M.; Reynaud, B. Tomato yellow leaf curl virus can be acquired and transmitted by Bemisia tabaci (Gennadius) from tomato fruit. Plant Dis. 2003, 87, 1297-1300.

35. Heikkilä, J; Vänninen, I. Impact Simulation of Bemisia tabaci. Natural Resources Institute Finland, Helsinki and Jokioinen, Finland. Unpublished data, 2015.

36. Vänninen, I.; Pereira-Querol, M.; Engeström, Y. Generating transformative agency among horticultural producers: An activity-theoretical approach to transforming. Int. Pest Manag. Agric. Syst. 2015, in press.

37. Bonato, O.; Lurette, A.; Vidal, C.; Fargues, J. Modelling temperature-dependent bionomics of Bemisia tabaci (Q-biotype). Physiol. Entomol. 2007, 32, 50-55.

38. Blackmer, J.L.; Lee, L.L.; Henneberry, T.J. Factors affecting egg hatch, development, and survival of Bemisia argentifolii (Hemiptera: Aleyrodidae) reared on an artificial feeding system. Environ. Entomol. 2002, 31, 306-312.

39. Yiejiang, C.; Hongwei, L.; Jian, H.; Qingzhu, H.; Yidi, X. Effect of photoperiod on the experimental population of sweetpotato whitefly, Bemisia tabaci (Gennadius). Entomol. J. East China 2002, 12, $38-41$.

40. Ovčarenko, I.; Kapantaidaki, D.E.; Lindström, L.M.; Gauthier, N.; Tsagkarakou, A.; Knott, K.E.; Vänninen, I. Agroecosystems shape population genetic structure of the greenhouse whitefly in Northern and Southern Europe. BMC Evol. Biol. 2014, 14, 165-181.

41. Ovčarenko, I.; Lindström, L.; Saikkonen, K.; Vänninen, I. Variation in mortality among populations is higher for pymetrozine, than for imidacloprid and spiromesifen in Trialeurodes vaporariorum in greenhouses in Finland. Pest Manag. Sci. 2014, 70, 1524-1530. 
42. DEFRA (Department for Environment, Food and Rural Affairs). Consultation on the UK Protected Zone (PZ) status of Bemisia tabaci (sweetpotato whitefly). Available online: https://secure.fera.defra.gov.uk/website2009/plants/plantHealth/pestsDiseases/documents/consultP rotectZone.pdf (accessed on 31 January 2015).

43. Zhang, G.-F.; Li, D.-C.; Liu, T.-X.; Wan, F.-H.; Wang, J.-J. Interspecific interactions between Bemisia tabaci biotype B and Trialeurodes vaporariorum (Hemiptera:Aleyrodidae). Environ. Entomol. 2011, 40, 140-150.

44. Heikkilä, J. Cost benefit analysis for the protected zone of Bemisia tabaci in Finland (in Finnish with English summary). Available online: http://www.mtt.fi/mtts/pdf/mtts170.pdf (accessed on 5 February 2015).

45. Cuthbertson, A.G.S.; Buxton, J.H.; Blackburn, L.F.; Mathers, J.J.; Robinson, K.; Powell, M.E.; Fleming, D.A.; Bell, H.A. Eradicating Bemisia tabaci Q on poinsettia plants in the UK. Crop Prot. 2012, 42, 42-48.

46. Cuthbertson, A.G.S.; Collins, D.A. Tri-Tek (petroleum horticultural oil) and Beauveria bassiana: Use in eradication strategies for Bemisia tabaci Mediterranean species in UK glasshouses. Insects 2015, 6, 133-140.

47. Cuthbertson, A.G.S. Fera, Sand Hutton, York, UK. Unpublished data, 2015.

(C) 2015 by the authors; licensee MDPI, Basel, Switzerland. This article is an open access article distributed under the terms and conditions of the Creative Commons Attribution license (http://creativecommons.org/licenses/by/3.0/). 